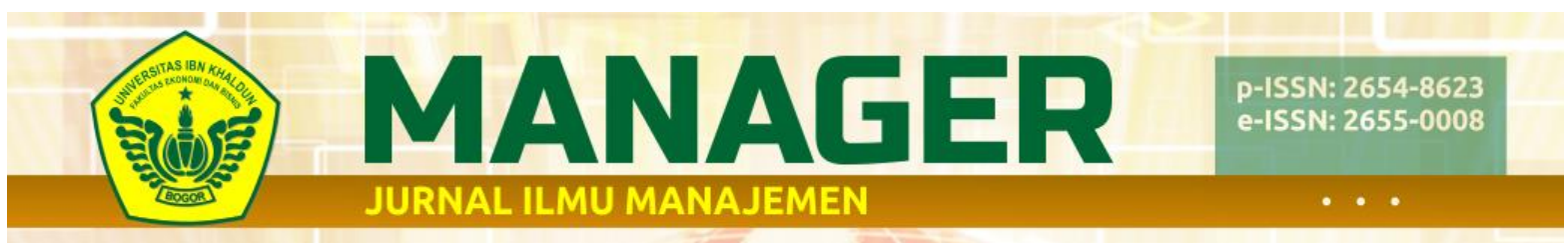

Vol. 3, No. 2, Mei 2020, Hal. 216-224 (c) (1) () http://ejournal.uikabogor.ac.id/index.php/Manager/index

\title{
PENGARUH DISTRIBUSI DAN PROMOSI PENJUALAN TERHADAP VOLUME PENJUALAN
}

\author{
Nurmala Sari, Achyar Eldine, dan Leny muniroh \\ Fakultas Ekonomi Dan Bisnis Universitas Ibn Khaldun Bogor, Indonesia \\ mala_inaya@yahoo.com, achyar@gmail.com, lenymuniroh@gmail.com
}

\begin{abstract}
The Effect of Distribution and Sales Promotion on Sales Volume at the Nissan-Datsun Dealer in Bogor Pajajaran Branch (Case Study of Nissan Grand Livina) Under the guidance of Mr. Achyar Eldine, SE., M.M and Mrs. Leny Muniroh, SE., M. Si This research was conducted at the Nissan-Datsun Pajajaran Bogor Dealer Company, located at Jl. Pajajaran No.55, Central Bogor. The company is engaged in Automotive. The purpose of this study is to Find out the Effect of Distribution and Sales Promotion on Sales Volume at Nissan-Datsun Dealers in Bogor Pajajaran Branch (Case Study of Nissan Grand Livina) Data analysis method used is secondary data processed with the help of SPSS Program 20. Data obtained from PT INDOMOBIL Company NATIONAL TRADA (Nissan-Datsun Dealer, Pajajaran Bogor Branch) Technical analysis used is Regression Analysis Test, Correlation Analysis, Determination Analysis, $T$ Test and $F$ Test. From the results of data management, we get the linear regression equation multiple $Y=(-76733619,063)+791,625 X 1+541,175 X 2$. The calculation result $R=0.961$ lies in the interval (0.80-1,000) or Positive and very Strong. This shows that the relationship between Variable X1 (Distribution) and Variable X2 (Sales promotion) to Variable Y (Sales Volume) is Positive and Very Strong. Furthermore, from the results of the Hypothesis test at the wrong level of 5\% is $f$ arithmetic $=24,658>f$ table $=$ 19.16 then Ho is rejected (Ha accepted), meaning that there is a significant relationship between sales contribution and sales promotion together against Sales Volume
\end{abstract}

Keywords: Distribution, sales promotion and sales volume

\begin{abstract}
Abstrak
Pengaruh Distribusi dan Promosi penjualan Terhadap Volume penjualan pada Dealer NissanDatsun Cabang pajajaran Bogor (Studi Kasus Nissan Grand livina) Dibawah Bimbingan Bapak Achyar Eldine, SE., M.M dan Ibu Leny Muniroh,SE., M. Si. Penelitian ini dilakukan pada Perusahaan Dealer Nissan-Datsun Cabang Pajajaran Bogor yang beralamatdi Jl.Pajajaran No.55 Bogor Tengah.Perusahaan ini bergerak dibidang Otomotif. Tujuan Penelitian ini adalah Mengertahui Pengaruh Distribusi dan Promosi penjualan Terhadap Volume penjualan pada Dealer Nissan-Datsun Cabang pajajaran Bogor (Studi Kasus Nissan Grand livina) Metode analisis data yang digunakan adalah data sekunder yang diolah dengan bantuan Program SPSS 20. Data diperoleh dari Perusahaan PT INDOMOBIL TRADA
\end{abstract}


NASIONAL (Dealer Nissan-Datsun Cabang pajajaran Bogor) Teknis analisis yang digunakan adalah Uji Analisis Regresi, Analisi Kolerasi, analisis Determinasi, Uji T dan Uji F. Dari hasil pengelolaan data diperoleh persamaan linier rergresi berganda $\mathrm{Y}=(-$ $76733619,063)+791,625 \mathrm{X} 1+541,175 \mathrm{X} 2$. Hasil perhitungan $\mathrm{R}=0,961$ terletak pada interval $(0,80-1,000)$ atau Positif dan sangat Kuat. Hal ini menunjukan bahwa hubungan antara Variabel X1 (Distribusi) dan Variabel X2 (Promosi penjualan) terhadap Variabel Y (Volume Penjualan) adalah Positif dan Sangat Kuat. Selanjutnya dari hasil uji Hipotesis pada taraf kesalah 5\% adalah $\mathrm{f}$ hitung $=24,658>\mathrm{f}$ tabel $=19,16$ maka Ho di tolak (Ha di terima), berarti bahwa terdapat hubungan yang signifikan antara Dstribusi dan Promosi penjualan secara bersama-sama terhadap Volume Penjualan.

\section{Kata kunci : Distribusi, Promosi penjualan dan Volume penjualan}

\section{Pendahuluan}

\section{Latar Belakang}

Kemajuan dunia otomotif saat ini sudah sangat berkembang pesat, kebutuhan akan transportasi adalah hal yang sangat penting bagi setiap kalangan konsumen.

Persaingan Industri otomotif di Indonesia berkembang sangat pesat dalam bentuk, variasi model, warna,kecanggihan teknologi dan merekmerek mobil yang ada dipasaran otomotif di Indonesia sekarang ini berasal dari buatan Eropa dan Asia seperti Honda, Daihatsu, Suzuki, Ford, Mitsubishi, KIA, Mazda, Proton, Toyota, Wuling dan Nissan, yang banyak diminati oleh masyarakat Indonesia. Setiap merek, produk yang ditawarkan pelayanan tersendiri untuk pelanggannya, berupa layanan purna jual, service, suku cadang, dan sampai penetapan harga yang cukup bersaing dengan jenis dan

\section{Tujuan Penelitian}

Adapun tujuan dari penelitian ini adalah:

1. Untuk mengetahui pengaruh Distribusi terhadap pengambilan keputusan pembelian mobil merek Nissan Grand livina pada PT Indomobil Trada Nasional Nissan-Datsun Cabang Pajajaran

2. Untuk mengetahui pengaruh promosi penjualan terhadap pengambilan segmen pasarnya. Salah satu perusahaan yang bergerak dalam industri otomotif, berupa penjualan dan service mobil merek Nissan yang terkenal diwilayah Bogor adalah PT Indomobil Trada Nasional Nissan-Datsun cabang Pajajaran. Produk mobil merek Nissan yang dipasarkan PT Indomobil Trada Nasional Nissan-Datsun cabang Pajajaran ini memiliki kelebihan dan ciri khas tersendiri dibandingkan dengan kendaraan jenis lain. Hal ini telah menjadi kebijaksanaan pemasaran perusahaan dengan harapan produk yang dipasarkan dapat menembus pasar, serta mampu meraih pangsa pasar yang luas. Untuk itu, maka tujuan untuk meningkatkan produk terutama bentuk, tipe, harga, serta daya tahan, dan merek yang dipasarkan harus dapat meningkatkan kepuasan konsumen.

keputusanpembelian mobil merek Nissan Grand livina pada PT. Indomobil Trada Nasional Nissan-Datsun Cabang Pajajaran

3. Untuk mengetahui pengaruh apakah Distribusi dan promosi penjualan terhadap pengambilan keputusan pembelian mobil merek Nissan grand 
4. livina pada PT Indomobil Trada Nasional Nissan-Datsun Cabang

\section{Metode penelitian}

\section{Teknik pengumpulan data}

Teknik pengumpulan data sebuah cara yang dilakukan oleh peneliti untuk mengumpulkan data. Pengumpulan data dilakukan adalah untuk memperoleh informasi yang dibutuhkan dalam rangka mencapai tujuan penelitian diantaranya :

a. Survei pendahuluan, yaitu mengadakan penelitian secara umum pada manajemen perusahaan untuk mengetahui permasalahan yang dihadapi secara lengkap dan jelas.

b. Studi lapangan dan penelitian, yaitu mengadakan pengamatan secara langsung untuk memperoleh data-data yang digunakan untuk bahan analisis pemecahan masalah

Dalam memperoleh data untuk penulisan penelitian ini, penulis menggunakan cara observasi tentang informasi data perusahaan yang ada, dikarenakan data ini bersifat data sekunder yaitu mencari data yang memang tidak terjun langsung keperusahaan tetapi melaui pencarian data atau informasi data yang ada, disitus internet lalu bisa dengan cara study perpustakaan (Library Research) atau yang diartikan pencarian suatu data yang ingin dikumpulkan dengan cara membaca laporan tahunan dan yang terakhir bisa melihat tulisan ilmiah serta tulisan yang dapat di perpustakaan seperti buku-buku yang ditulis para ahli dibidangnya.

\section{Hasil Pembahasan}

Pengaruh Distribusi (X1) Terhadap volume penjualan $(\mathrm{Y})$

Berdasarkan perhitungan koefisien regresi pada, dapat diketahui persamaan regresi yang terbentuk adalah : $Y=-172495138,353+1906,715 X 1$
Pajajaran

\begin{tabular}{llrrr}
\multicolumn{5}{c}{ Model Summary } \\
\hline $\begin{array}{l}\text { Mod } \\
\text { el }\end{array}$ & R & $\begin{array}{c}\text { R } \\
\text { Square }\end{array}$ & $\begin{array}{c}\text { Adjusted R } \\
\text { Square }\end{array}$ & $\begin{array}{l}\text { Std. Error } \\
\text { of the } \\
\text { Estimate }\end{array}$ \\
\hline 1 &, $886^{\mathrm{a}}$ &, 784 &, 712 & $\begin{array}{r}14400898,4 \\
5621\end{array}$ \\
\hline
\end{tabular}

a. Predictors: (Constant), Distribusi

Analisis ini digunakan untuk mengetahui Distribusi (X1) Terhadap Volume penjualan (Y) yang diperoleh adalah sebagai berikut :

\section{Tabel 1 Hasil analisis kolerasi Distribusi (X1) Terhadap volume penjualan (Y)}

Dari hasil perhitungan table diatas dapat diketahui hasil hubungan antara Distribusi (X1) dengan Volume penjulan (Y) penjualan memiliki $\mathrm{R}=$ 0,886 Terletak pada Interval $(0,80$ $1,00)$ ), hal ini menunjukan terdapat hubungan yang sangat kuat dan positif

\section{Hasil analisis Regresi}

Analisis Regresi dimaksudkan untuk mengetahui antara Distribusi (X1) dan Volume penjualan (Y) dengan menggunakan perhitungan SPSS 20 Hasil yang diperoleh adalah sebagai berikut :

$$
\begin{aligned}
& \mathrm{Y}=\mathrm{a}+\mathrm{b} \mathrm{X} 1 \\
& \mathrm{X} 1=\text { Distribusi } \\
& \mathrm{a}=\text { Intercept dan Konstanta } \\
& \mathrm{b}=\text { Koefisien Regresi }
\end{aligned}
$$

Interpretasi dari persamaan tersebut adalah sebagai berikut :

1. Intercept atau Konstanta sebesar dimana $\quad-172495138,353$ berarti 
apabila Variabel bebas X1 (Distribusi ) sama dengan nol, maka besarnya variable Y (Volume Penjualan) adalah -172495138,353 dengan kata lain ada potensi penjualan sebesar 172495138,353 (konstanta bilangan mutlak)

2. Arah hubungan dan Koefisien Regresi Variabel X1 (Distribusi) sebesar 1906,715 ini berarti berarti pengaruh Distribusi (X1) terhadap Volume Penjualan (Y) adalah positif atau setiap kenaikan nilai skor variabel $\mathrm{X} 1$ (Distribusi) sebesar 1906,715 maka akan meningkatkan nilai skor Variabel Y (Volume Penjualan).

\section{Koefisien Determinasi}

Pada tabel 2 dapat dilihat hasil koefisien Determinasi sebesar 0,784 atau $(78,4 \%)$ memberikan arti bahwa besarnya peranan Distribusi terhadap penjualan, sedangkan $21,6 \%$ dipengaruhi oleh factorfaktor lain yang tidak dimasukan dalam penelitian ini.

\section{Uji T (Uji Hipotesis)}

a. Formulasi Hipotesis

Ho = Tidak ada Hubungan yang signifikan antara Distribusi terhadap Volime penjualan

\section{Tabel 2 Hasil analisis kolerasi \\ promosi penjualan (X2) Terhadap volume penjualan (Y)}

Model Summary

\begin{tabular}{|c|c|c|c|c|}
\hline \multicolumn{5}{|c|}{ Model Summary } \\
\hline Model & $\mathrm{R}$ & R Square & Adjusted R Square & $\begin{array}{l}\text { Std. Error of the } \\
\text { Estimate }\end{array}$ \\
\hline 1 &, $953^{\mathrm{a}}$ & ,907 & ,876 & 9436588,83923 \\
\hline
\end{tabular}

Dari hasil Dari hasil perhitungan Tabel 11 diatas dapat diketahui hasil hubungan antara Promosi penjualan (X2) dengan Volume penjulan (Y) penjualan
$\mathrm{Ha}=$ Terdapat hubungan yang signifikan antara Distribusi terhadap Volime penjualan

b. Taraf Nyata

Taraf nyata $95 \%$, maka nilai $\alpha=5$ $\%$ atau $(0,05)$ nilai $\mathrm{t}$ tabel memiliki derajat bebas $(\mathrm{db})=5-2=3$

$\mathrm{t}_{\text {tabel }}=2,35336$

c. Kriteria pengujian

Ho diterima (Ha ditolak) apabila $\mathrm{t}_{\text {hitung }}<\mathrm{t}_{\text {tabel }}$

Ho ditolak (Ha diterima) apabila $\mathrm{t}_{\text {hitung }}>\mathrm{t}_{\text {table }}$

d. Nilai uji statistik

Berdasarkan perhitungan spss 20 dapat dilihat pada Tabel bahwa $t_{\text {hitung }}=3,301$

e. Kesimpulan

Karena $t_{\text {hitung }}=3,301>\mathrm{t}$ tabel $=$ 2,35336, maka Ho ditolak (Ha diterima), Berarti bahwa terdapat hubungan yang signifikan antara Distribusi dengan Volume penjualan

Pengaruh promosi penjualan (X2) Terhadap volume penjualan (Y)

Analisis ini digunakan untuk mengetahui promosi penjualan (X2) Terhadap Volume penjualan (Y) yang diperoleh adalah sebagai berikut : $(0,80-1,00)$, hal ini menunjukan terdapat hubungan yang sangat kuat dan positif.

\section{Hasil analisis Regresi}


Analisis Regresi dimaksudkan untuk $\mathrm{Y}=\mathrm{a}+\mathrm{b}$ X2 mengetahui antara Distribusi (X1) dan $\mathrm{X} 2=$ Promosi penjualan Volume penjualan (Y) dengan $\mathrm{a}=$ Intercept dan Konstanta menggunakan perhitungan SPSS 20 Hasil $\quad b=$ Koefisien Regresi yang diperoleh adalah sebagai berikut :

\section{Tabel 3 Hasil analisis Regresi}

Promosi penjualan (X2) denganVolume penjualan (Y)

\section{Coefficients $^{\mathrm{a}}$}

\begin{tabular}{|c|c|c|c|c|c|c|}
\hline \multicolumn{2}{|r|}{ Model } & \multicolumn{2}{|c|}{ Unstandardized Coefficients } & \multirow{2}{*}{$\begin{array}{c}\begin{array}{c}\text { Standardized } \\
\text { Coefficients }\end{array} \\
\text { Beta }\end{array}$} & \multirow[t]{2}{*}{$\mathrm{t}$} & \multirow[t]{2}{*}{ Sig. } \\
\hline & & B & Std. Error & & & \\
\hline \multirow{2}{*}{1} & (Constant) & 1036483,709 & $\begin{array}{c}10066368,35 \\
9\end{array}$ & &, 103 & ,924 \\
\hline & $\begin{array}{c}\text { Promosipenjuala } \\
\mathrm{n}\end{array}$ & 772,668 & 142,588 & ,953 & 5,419 & ,012 \\
\hline
\end{tabular}

a. Dependent Variable: Volumepenjualan

Berdasarkan perhitungan koefisien regresi pada Tabel 12, dapat diketahui persamaan regresi yang terbentuk adalah: $\mathrm{Y}=1036483,709+772,668 \mathrm{X} 2$ Interpretasi dari persamaan tersebut adalah sebagai berikut :

1. Intercept atau Konstanta sebesar dimana $-1036483,709$ berarti apabila Variabel bebas X2 ( Promosi penjualan ) sama dengan nol, maka besarnya variable $\mathrm{Y}$ (Volume Penjualan) adalah 1036483,709 dengan kata lain ada potensi penjualan sebesar 1036483,709

2. Variabel X2 (Promosi penjualan) sebesar 772,668 ini berarti berarti pengaruh Promosi penjualan (X2) terhadap Volume Penjualan (Y)

3. Pada tabel 4 dapat dilihat hasil koefisien Determinasi sebesar 0,907 atau $(90,7 \%)$ memberikan arti bahwa besarnya peranan Distribusi terhadap penjualan, sedangkan 9,3\% dipengaruhi oleh factor-faktor lain yang tidak dimasukan dalam penelitian ini.
4. Uji T (Uji Hipotesis)

a. Formulasi Hipotesis

Ho = Tidak ada Hubungan yang signifikan antara Distribusi terhadap Volime penjualan $\mathrm{Ha}=$ Terdapat hubungan yang signifikan antara Distribusi terhadap Volime penjualan

b. Taraf Nyata Taraf nyata $95 \%$, maka nilai $\alpha=$ $5 \%$ atau $(0,05)$ nilai $t_{\text {tabel }}$ memiliki derajat bebas $(\mathrm{db})=5-2=3 \mathrm{t}_{\text {tabel }}=$ 2,35336

c. Kriteria pengujian

Ho diterima (Ha ditolak) apabila $\mathrm{t}_{\text {hitung }}<\mathrm{t}_{\text {tabel }}$

Ho ditolak (Ha diterima) apabila $t_{\text {hitung }}>t_{\text {table }}$

d. Nilai uji statistik

Berdasarkan perhitungan spss 20 dapat dilihat pada Tabel bahwa $\mathrm{t}_{\text {hitung }}=5,419$

e. Kesimpulan

Karena $t_{\text {hitung }}=5,419>\mathrm{t}$ tabel $=$ 2,35336, maka Ho ditolak (Ha diterima), Berarti bahwa terdapat 
hubungan yang signifikan antara

Distribusi dengan Volume penjualan. penjualan (Y), dengan menggunakan perhitungan SPSS 20 Hasil yang diperoleh adalah sebagai berikut :

\section{Korelasi berganda}

Analisis ini digunakan untuk mengetahui Distribusi (X1) dan Promosi penjualan (X2) Terhadap Volume

Model Summary

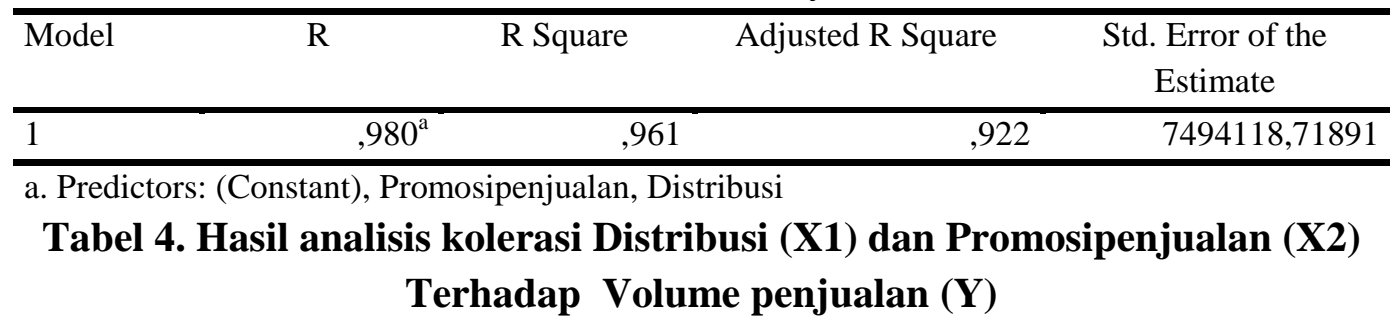

Dari hasil perhitungan pada tabel 5 diatas $\mathrm{R}=0,980$ atau $98 \%$ terletak pada interval $(0,80-1,00)$, hal ini menunjukan bahwa antara variabel $\mathrm{X} 1$ (Distribusi) dan X2 (Promosi penjualan) secara bersama-sama terhadap Y (Volume Penjualan) adalah Sangat Kuat dan Positif. Berarti secara bersama-sama kenaikan X1 dan X2 akan menyebabkan kenaikan Y.

Analisis Regresi berganda dimaksudkan untuk mengetahui antara Disriusi (X1) Promosi penjualan (X2) dan Volume penjualan (Y) dengan menggunakan perhitungan SPSS 20 Hasil yang diperoleh adalah sebagai berikut

Tabel 5. Hasil analisis Regresi antara Distribusi (X1) dan Promosi penjualan (X2) dengan Volume penjualan (Y)

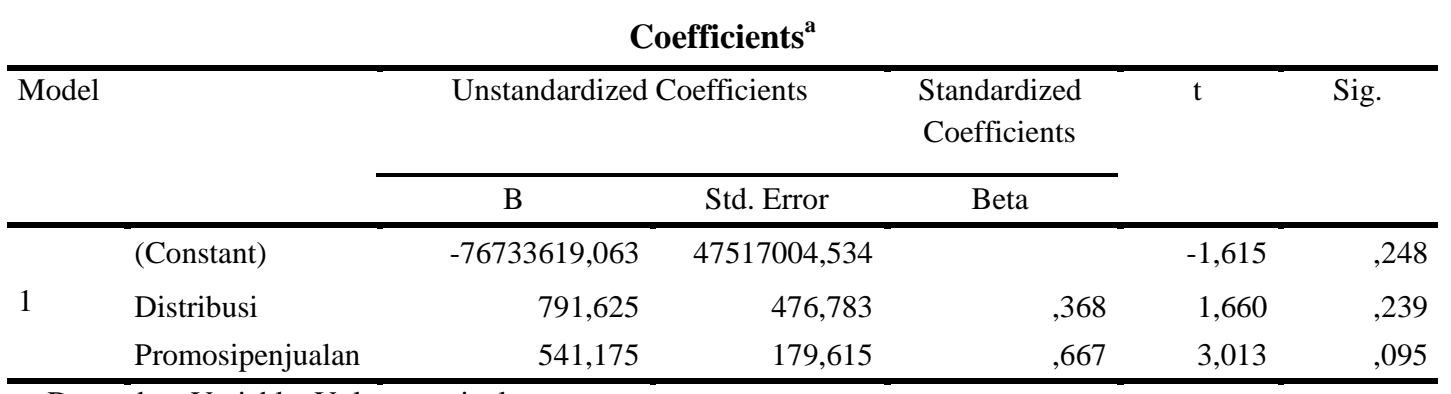

a. Dependent Variable: Volumepenjualan

Berdasarkan perhitungan koefisien regresi pada Tabel 6 , dapat diketahui persamaan regresi yang terbentuk adalah:

$$
\begin{aligned}
& Y=(-76733619,063)+791,625 \\
& X 1+541,175 X 2
\end{aligned}
$$


Interpretasi dari persamaan tersebut adalah sebagai berikut :

1. Intercept atau Konstanta sebesar dimana $-76733619,063$ berarti apabila Variabel bebas X1 (Distribusi) dan X2 (Promosi penjualan ) sama dengan nol, maka besarnya variable $\mathrm{Y}$ (Volume Penjualan) adalah 76733619,063 dengan kata lain ada potensi penjualan sebesar 76733619,063

(konstanta bilangan mutlak)

2. Arah hubungan dan Koefisien Regresi Variabel X1 (Distribusi) sebesar 791,625 ini berarti pengaruh distribusi terhadap Volume penjualan (Y) positif. Dan Variabel X2 (Promosi penjualan) sebesar 541,175 ini berarti pengaruh distribusi terhadap Volume penjualan (Y) positif. setiap kenaikan nilai skor dua variabel X1 (Distribusi) dan $\mathrm{X} 2$ (Promosi penjualan) maka akan meningkatkan nilai skor Variabel Y (Volume Penjualan)

\section{Koefisien Determinasi}

Pada tabel 6 dapat dilihat hasil koefisien Determinasi sebesar 0,961 9atau $(96,1 \%)$ memberikan arti bahwa besarnya peranan Distribusi terhadap penjualan, sedangkan 3,9\%dipengaruhi oleh factorfaktor lain yang tidak dimasukan dalam penelitian ini.

a. Formulasi Hipotesis

Ho = Tidak ada prengaruh yang signifikan antara Sales Promtion dan Harga seacara bersama-sama terhadap Volume Penjualan.

$\mathrm{Ha}=$ Terdapat hubungan yang signifikan anttara Sales Promotion dan

\section{Uji T (Uji Hipotesis)}

Formulasi Hipotesis

Ho $=$ Tidak ada Hubungan yang signifikan antara Distribusi terhadap Volime penjualan

$\mathrm{Ha}=$ Terdapat hubungan yang signifikan antara Distribusi terhadap Volime penjualan

Taraf Nyata

Taraf nyata 95\%, maka nilai $\alpha=5 \%$ atau $(0,05)$ nilai $t$ table memiliki derajat bebas $(\mathrm{db})=5-2=3 \quad \mathrm{t}_{\text {tabel }}=2,35336$

Kriteria pengujian

Ho diterima (Ha ditolak) apabila $\mathrm{t}_{\text {hitung }}<\mathrm{t}$ tabel

Ho ditolak (Ha diterima) apabila $t_{\text {hitung }}>t$ table

Nilai uji statistic

Karena $t_{\text {hitung }}=2,811>\mathrm{t}_{\text {tabel }}=2,35336$, maka Ho ditolak (Ha diterima), Berarti bahwa terdapat hubungan yang signifikan antara Distribusi dengan Volume penjualan

Uji F

Uji $F$ atau Uji Anova, yaitu uji untuk melihat bagaimanakah pengaruh semua variabel X1 Distribusi dan Promosi penjualan X2 secara bersama-sama terhadap variabel terikatnya. Atau untuk menguji apakah model regresi yang kita buat baik/ signifikan atau tidak baik/ non signifikan.

Harga secara bersama-sama terhadap Volume Penjualan.

b. Taraf Nyata

Taraf nyata $95 \%$, maka nilai $a=5 \%$ atau $(0,05)$

Nilai F tabel dengan 
$\mathrm{V} 1=\mathrm{dk}$ pembilang $=\mathrm{k}=2 \mathrm{~V} 2=\mathrm{dk}$

penyebut $=\mathrm{n}-\mathrm{k}-1=5-2-1=3$

$$
\mathrm{F} \text { tabel }=19,16
$$

\section{c. Kriteria Pengujian}

Ho diterima (Ha di tolak) apabila $\mathrm{t}$ hitung $<\mathrm{f}$ tabel

Ho ditolak (Ha di terima) apabila t hitung $>\mathrm{f}$ tabel

d. Nilai Uji Statistik

Berdasarkan perhitungan dengan

\section{Kesimpulan dan Saran}

\section{Kesimpulan}

1. Pengaruh Distribusi Terhadap volume penjualan menunjukan uji hipotesis pada taraf kesalahan 5\% adalah $\mathrm{t}_{\text {hitung }}=791,625>\mathrm{t}$ tabel $=$ 2,35336, maka Ho ditolak (Ha diterima), Berarti bahwa terdapat hubungan yang signifikan antara Distribusi dengan Volume penjualan.

2. Pengaruh Promosi penjualan terhadap volume penjualan menunjukan uji hipotesis pada taraf kesalahan $5 \%$ adalah $t_{\text {hitung }}=$ $541,175>\mathrm{t}_{\text {tabel }}=2,35336$, maka Ho ditolak (Ha diterima), Berarti bahwa terdapat hubungan yang signifikan antara promosi penjualan dengan Volume penjualan.

3. Pengaruh Distribusi dan Promosi penjualan terhadap volume penjualan menunjukan hubungan yang kuat dan positif. Hal ini ditunjukan dari hasil perhitungan data pengujian hipotesis dengan nilai $\mathrm{R}=0,995$ Terletak pada interval (0,80-1,000) atau 99,5\% yang memiliki arti hubungan sangat kuat dan positif. Dari hasil analisis $\mathrm{R}$ square 0,947 memberikan arti bahwa promosi penjualan terhadap volume
SPSS 20 dapat dilihat pada Tabel , bahwa f hitung $=24,658$

e. Kesimpulan

Karena f hitung $=24,658>\mathrm{f}$ tabel = 19,16 maka Ho di tolak (Ha di terima), berarti bahwa terdapat hubungan yang signifikan antara Dstribusi dan Promosi penjualan secara bersama-sama terhadap Volume Penjualan.

penjualan sebesar $94,7 \%$ sedangkan sisanya $5,3 \quad \%$ dipengaruhi oleh factor-faktor lain yang tidak dimasukan dalam penelitian ini. Berdasarkan hasil uji $F$ diketahui bahwa variabel distribusi dan variabel saluran promosi secara simultan berpengaruh signifikan terhadap volume penjualan, hipotesis pada taraf kesalahan $5 \%$ adalah $\mathrm{F}$ hitung $=24,658>\mathrm{f}$ tabel $=19,16 \%$, maka Ho ditolak (Ha diterima), berarti bahwa terdapat pengaruh yang signifian antara Pengaruh Distribusi dan Promosi Penjualan secara bersama-sama terhadap Volume Penjualan.

\section{Saran}

1. Hasil penelitian menunjukkan bahwa variabel distribusi lebih besar pengaruhnya daripada variabel promosi, untuk meningkatkan volume penjualan maka dapat dilakukan dengan cara meningkatkan dan menambahkan saluran distibusi sehingga produk perusahaan bisa dikenal dengan luas.

2. Promosi perusahaan juga perlu diperhatikan, untuk mendukung saluran Distribusi agar bisa lebih luas, promosi penjualan perusahaan 
harus mempertimbangkan untuk menambah kegiatan promosi perusahaan, akan lebih baik jika menggunakan menambah media promosi melalui internet misalnya dengan mengembangkan website perusahaan juga website personal selling dan juga meningkatkan

\section{Daftar Pustaka}

Ansah, A. (2017). Pengaruh Desain Produk, Promosi, dan citra merek terhadap keputusan pembelian 1 , 12.

Arifin, S. (2019). Pemasaran Era milenium deepublish.

Darmanto, \& wardaya, S. (2012). Manajemen pemasaran untuk mahasiswa, usaha mikro,kecil dan menengah. DIY.

Daryanto. (2013). Sari kuliah Manajemen Pemasaran Bandung. PT Sarana Tutorial Nurani sejahtera.

Ginting, H. (2014). Manajemen Pemasaran. Bandung: PT Sarana Tutorial Nurani sejahtera hang suryanto, mikael. (2016). Sistem Operasional Manajemen Distribusi. PT Grasindo.

Kotler, P. (t.t.). Marketing Insights from A TO Z. Jakarta: Erlangga.

Kotler, P., \& Keller, K. L. (2009). Manajemen Pemasaran. Indonesia: Erlangga.

Nazir, moh. (t.t.). Metode Penelitian. ciawi-bogor: ghalia indonesi.

Peter, J. P., \& Olson, J. C. (2014). Perilaku Konsumen \& Strategi Pemasaran. Jakarta: Salemba Empat.

Rangkuti, F. (2009). Strategi promosi yang kreatif \& analisa kasus integrated marketing communication. Jakarta: Gramedia Utama. periklanan melalui jejaring sosial seperti facebook, twitter, instagram dan lain-lain. Jika semakin baik promosi penjualan dan saluran disrtibusi yang dilakukan oleh perusahan dapat membantu meningkatkan volume penjualan perusahaan.

Sinulingga, N. A. B. (2015). Pengaruh strategi pemasaran terhadap volume penjualan pada PT. Citramandiri Lestari Medan. 17(1), 5.

Siyoto, S., \& Sodik, M. A. (2015). Dasar Metodologi Penelitian. Indonesia: Literasi Media.

Soegoto, E. soeryanto. (2013). Marketing research The Smart Way To Solve a problem. Elex Media Komputindo.

\section{Jurnal:}

Fauziah, U. U., Eldine, A., \& Sume, S. A. (t.t.). Sales Promotion Dan Harga Terhadap Volume Penjualan. 16.

Muniroh, L., . H., \& Marlina, A. (2017). Manfaat penggunaan media sosial terhadap peeningkatan penjualan tas pada pengrajin tas di Ciampea. INOVATOR, 6(2), 57. https://doi.org/10.32832/inovator.v6 i2.1046

Ramadhan, P. A., \& Afandi, Y. (t.t.). Pengaruh promosi dan saluran distribusi terhadap volume penjualan pada PT Rajawali Nusindo Cabang Malang. 6.

Tsani, A., \& Sume, S. A. (t.t.). Harga Dan Promosi Terhadap Volume Penjualan. 10.

Widyana, N. A., Eldine, A., \& Muniroh, L. (t.t.). Daya Tarik Iklan Terhadap Keputusan Pembelian. 12. 